\title{
ASSESSING IMPACT OF 'AMAR BARI AMAR KHAMAR' PROJECT ON POVERTY REDUCTION: A CASE STUDY ON DIGHALIA UPAZILLA, KHULNA
}

\author{
Sharfan Upaul*1, Anika Ibnat Chowdhury ${ }^{2}$, Sk Farzana Faruk Nitu ${ }^{3}$ \\ 1. *Corresponding Author : Department of Urban and Regional Planning, Khulna University of Engineering and \\ Technology, Bangladesh.Email: u.sharfan5050@gmail.com \\ 3. Department of Urban and Regional Planning, Khulna University of Engineering and Technology, Bangladesh \\ 2. Department of Urban and Regional Planning, Khulna University of Engineering and Technology, Bangladesh
}

\begin{abstract}
The study attempts to assess the "Amar Bari Amar Khamar (ABAK)" project's criteria strategically. The ABAK project targets poverty in Bangladesh, and strategies are the economic development of the rural areas and develop social and women empowering conditions. The assessment would be a fruitful way to indicate the underlying factors and the magnitude of the project's succession in livelihood outcomes. The impact and change in the post-project period had been signified through the factors of the livelihood framework. A field survey was done through a questionnaire to collect the research data. Both quantitative and qualitative methods were done; the pear sample t-test was used to identify the change, and the multiple regression model and indices were used to measure poverty. Income sectors were found changed from agricultural to non-agricultural based. Despite all positive changes to the capital assets, the project had limited success in poverty reduction. Savings and women empowerment were prominent in the post-project period. A user-friendly loaning policy will help to gain the ultimate success in poverty reduction in the vulnerability context.
\end{abstract}

KEYWORDS: Assessment, Impact, Amar Bari Amar Khamar, Poverty reduction, Khulna

\section{INTRODUCTION}

The study intends to evaluate the role of the "Amar Bari Amar Khamar (ABAK)" project in the poverty reduction of Dighalia Upazila in the Khulna district. It tries to find out the performance of the project in terms of livelihood framework components. Since the project started in 2009 and still working on poverty elimination and developing a living standard of more impoverished people by developing micro capital and micro-savings at the individual level, it is necessary to identify its magnitude of successiveness. As most people in Bangladesh are involved in agriculture, the project's primary concern is to impose on the agricultural background to strengthen rural areas' micro capital system. Therefore, it is relevant to assess the project's impact to find the crucial factors underlying it as a driver for a long-term project in the study area and the whole country.

First, the Japanese government initiated this type of project titled "One Village One Product" (OVOP) in 1980, which produces only quality-oriented products made from only local raw materials and by local resources. Another project introduced by the Thailand government was named "One Tambon One Product" (OTOP) in 2001, which also produced excellent products 
using raw materials from the village area. These projects were primarily based on the cultivation of products, marketing, and value addition (Howlader H. O., 2017). After the independence of Bangladesh, it had formed the village government to develop the village poor's socioeconomic condition. Bangladesh has a long and elaborate history in the field of rural development, such as V-AID, Comilla model, Swanirvar (self-reliance) and NGOs Bangladesh Rural Advancement Committee (BRAC), Grameen Bank, etc. (Begum, 2015).

All those programs were run in the country for a limited period. For example, the V-AID program launched in the country in 1953 covered all the sectors such as agriculture, sanitation, education, cooperatives, and housing, but due to lack of proper rapport building, it was collapsed (Banglapedia, 2015a). Due to proper social stratification, the Swanirvar (self-reliance)movement also shut down, although it could hold a large scale of beneficiaries (Banglapedia, 2015b). Again NGOs working with this sector (i.e., Grameen Bank) also been criticized for their faulty management system (Roodman, Grameen Bank Portfolio Continues Deteriorating, 2012). In that perspective, "Amar Bari Amar Khamar" is the most recent and ongoing project, working on quality development of life by socioeconomic development and creating enthusiasm in micro-savings, women empowerment, and so on. Besides, as the previous programs fail to significantly reduce the poverty rate (only 1\% yearly reduction since 1990-2010 (Nokrek et al., 2018), the study tries to focus on evaluating the effect of the project refurnished the condition of the study area, or the strategies are not implemented affluently to reduce poverty. A few works on the evaluation of criteria of ABAK, so for any further analysis on rural development of Bangladesh, especially assessment on ABAK, will be able to pursue data and information from this study and draw an idea of the composition of analysis. The study enhanced the experience of evaluating strategies and findings of the analysis. A study on "Amar Bari Amar Khamar" was done before (Howlader H. O., 2017), on an overall review of Bangladesh's eight-division. However, the study was only done on giving importance to micro-savings implemented by ABAK. In that perspective, the study of ABAK is strategically different from another project because this project encourages the disadvantaged population through upgrading them from poverty, providing essential support by the government, promoting savings tendency among the poor by giving interest allowance. As several authors (Hossain et al., 2012; Nokrek et al., 2018) measured the past project's performance in the country, in that perspective, being an ongoing and primarily considered successful project $\mathrm{ABAK}$ also demands a performance evaluation, and in that point, the study works out.

\section{LITERATURE REVIEW}

Researchers tried to determine the crucial factors behind rural people's socioeconomic development (Talukder \& Chile, 2014; Ahmed \& Sattar, 2004). Gainee (2014) represents rural development as improving the quality of life and economic beneficiaries of people living in relatively isolated and less populated areas. Some authors, while measuring the performance of development projects, focused on the agriculture sector only, forming agricultural-based criteria (i.e., Rice production per capita, amount of harvested areas, land ownership, workers' salary) with the educational performance (i.e., literacy rate, child enrolment in school) associated with 
the planning perspectives during that projects. Again, Nokrek et al. (2018) determined the poverty and income inequality in ethnic communities of Bangladesh considering household income (agricultural and non-agricultural), the amount of cultivated land (rented and owned) along with the number of workers and their salary.

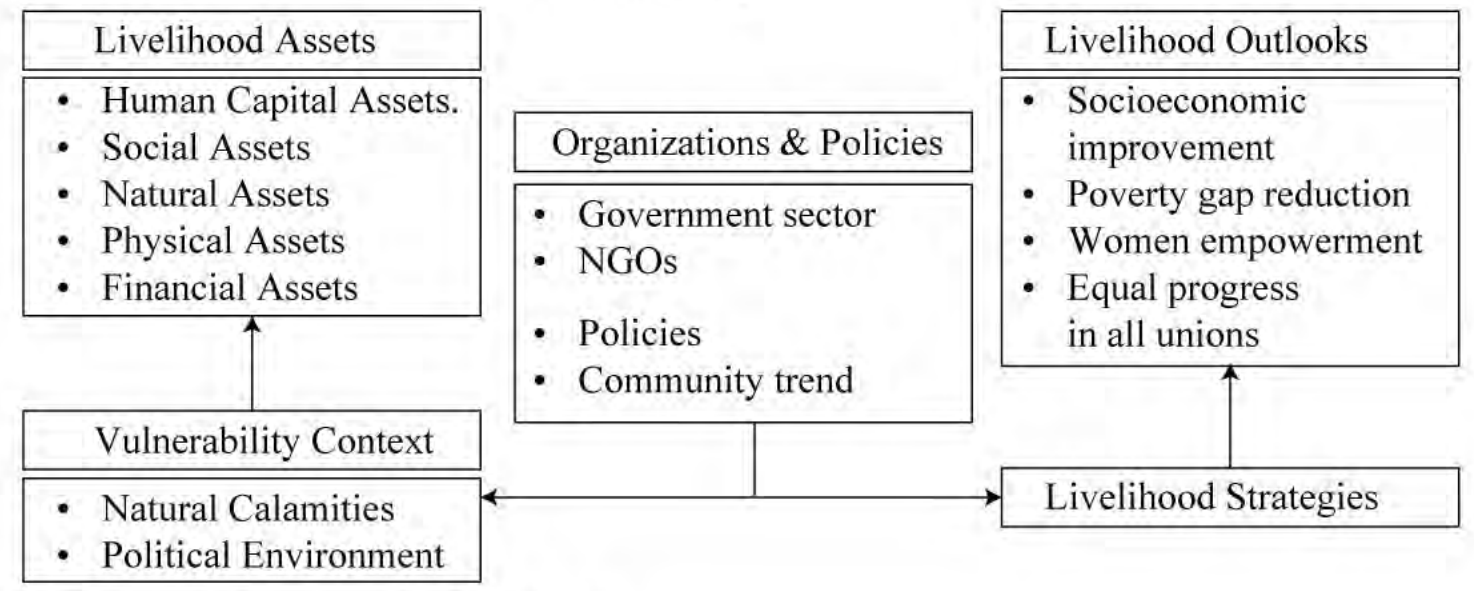

Fig. 1: Conceptual framework for livelihood

Source: Author, 2019

The measurement of the development project's performance (UNDP, 2017) provided a comprehensive "Livelihood Framework" based analysis. Their guidelines showed how livelihood assets influence vulnerability and livelihood strategies and improve livelihood outcomes. Some authors used the modified framework to justify socio-environmental systems' vulnerability in different parts of the world (Gupta et al., 2019). The study also uses the livelihood framework for the evaluation process. The abstract of this study's framework has been adopted from the Department for International Development (DFID), who provided the first holistic framework for livelihood performance measurement (GLOPP, 2008). Fig :1, represents the framework for the ABEK's evaluation for the respective study area. The framework consists of five types of significant holistic livelihood assets. Harper et al. (2020) provide a guideline for the components of the livelihood assets.

All the skills and health benefits can be considered as human capital assets. In social assets, occupational groups, or any other social bonding that helps produce positive change can be considered social assets. The amount of cultivable land is considered under natural assets. Physical assets consist of the house they owned, structural types of the house, and the everyday electronics the participants owned, which have a current monetary value. The monetary inflow and increment to the participants are as financial assets (income and saving).

On the other hand, vulnerabilities are considered the shocks that hamper the livelihood's expected outcome. These are necessary influencers (i.e., inflation in the market, investment failure) and the surrounding environment (natural and political calamities). Rural people's livelihood strategies are most common but diversified, and this section covers the means of their existent in that society and the policies of their balancing of income and expenditure, which 
enable them to save. Those strategies help maintain livelihood security and earn the expected livelihood outcomes (Harper et al., 2020). The most common expected livelihood outcome is the community's sustainable condition, which consists of income increment, low wealth inequality, improved socioeconomic condition, and reduced poverty rate (GLOPP, 2008). The rural development projects participant often follows some strategy to gain from the capital assets and reach expected outcomes (Manlosa et al., 2019).

\section{MATERIALS AND METHODS}

The study area was Dighalia Upazila in Khulna district, three unions of Dighalia (Jogipole, Arongghata, and Senhati) area were taken (Fig: 2). This research was done under the specific sessional course of the urban and regional planning department in Khulna University of Engineering and Technology (KUET), where due to the vast study area (including other Upazila in Khulna district), this particular group chooses the study area for better access from the institution (as it nearby) and the convenience of the survey. A stratified random sampling method was chosen to proceed with the study, and the sample size was 60 (only the members of ABAK were taken as samples). The sample size was taken, considering to survey 20 nos./union (total three unions) for the survey's convenience as the primary data was conducted by field survey. Various secondary data (i.e., geographic location of the study area, demographic information of the study people, natural calamities, etc.) have been collected from published articles, materials, official records of various involved agencies. Both qualitative and quantitative methods were done for the measurement of impact. Pear sample t-test was performed for each pear to show the change of pre and post-project. The factors were absorbed from the livelihood framework (see fig. 1 for details). Table 1 represents the factors and its subfactors and variables, describing the measurement methods of those variables. The capital assets were divided (Fig. 1) into its five major categories, which determined by skills (i.e., educational and training) and the participant's health benefit. Grouping in the community was set in the social category, and all of this was measured by yes/no of the respondent, and then the mean is compared with a t-test. In the natural group, only the farmland data was possible to collect. Sanitation and housing types (physical assets) were categorized for covering commonly used structures, and most used electronic devices (i.e., TV, mobile, etc.) were included in this sector. For financial capital, both agro-based (i.e., crops, fishing, etc.) and non-agricultural income had been considered along with a common form of saving sectors (i.e., bank, post office, etc.) 


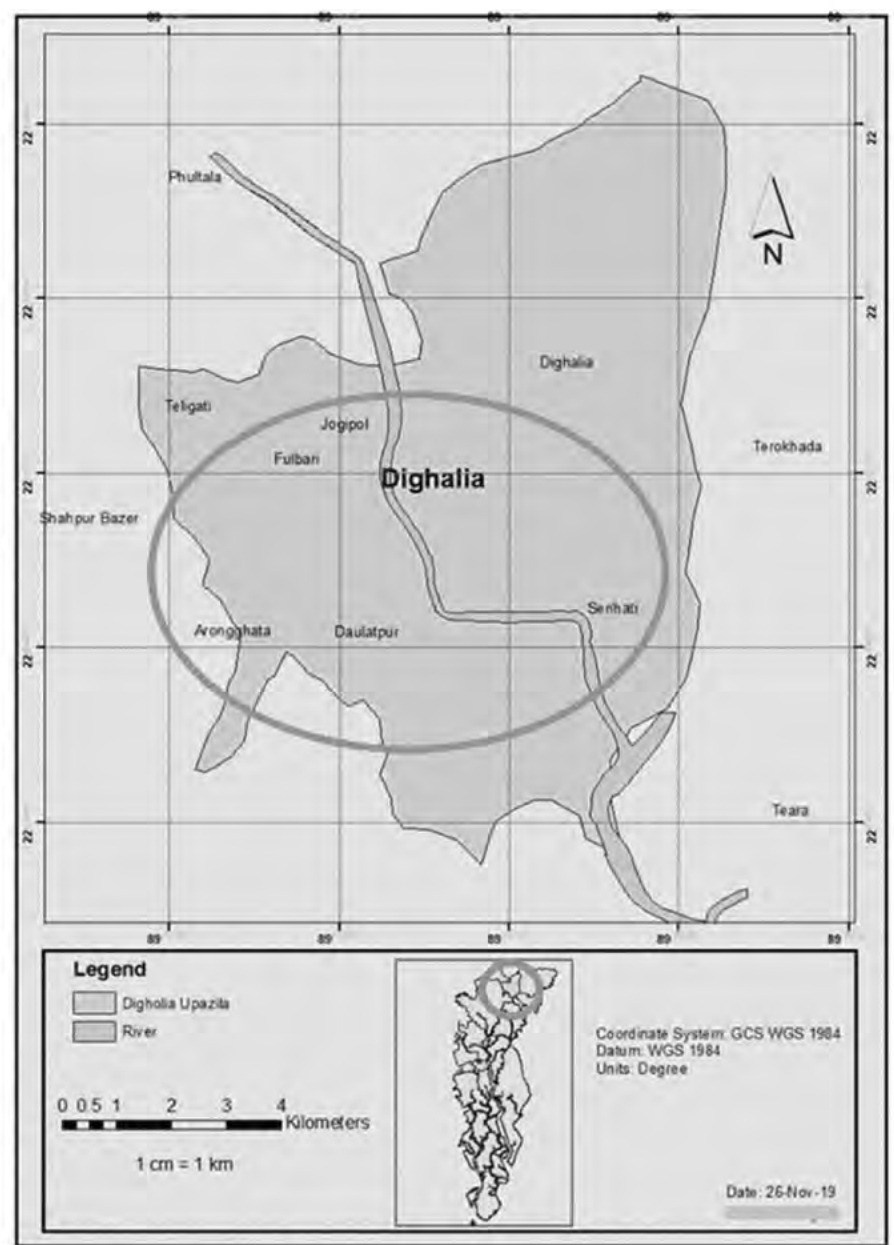

Fig. 2: Location of the study area

Source: Author, 2019

All investments were taken lump sum to reduce the complexity of variables. Most common natural calamities that could affect the production line and exposer during disaster participants are taken in the vulnerability context. The past studies found that people were interested in this type of project to take the loan and invest as a livelihood strategy. So those factors, along with the saving structure, had been added as a coping strategy.

Table 1: Criteria for the impact assessment with associate variables and measurement

\begin{tabular}{|l|l|l|l|}
\hline Type of factors & Sub factors & Variables & Measurement \\
\hline Capital Assets & Human capital assets & $\begin{array}{l}\text { Children enrolment in } \\
\text { education }\end{array}$ & Change measurement ( $1=$ No, 2 = Yes $)$ \\
\cline { 3 - 5 } & & Health Improvement & Change measurement ( $0=$ No, $1=$ Yes $)$ \\
\cline { 3 - 4 } & & Training benefit & Change measurement ( $0=$ No, $1=$ Yes $)$ \\
\hline
\end{tabular}




\begin{tabular}{|c|c|c|c|}
\hline Type of factors & Sub factors & Variables & Measurement \\
\hline & \multirow[t]{2}{*}{ Social capital assets } & $\begin{array}{l}\text { Entertainment group } \\
\text { involvement }\end{array}$ & Change measurement $(0=\mathrm{No}, 1=\mathrm{Yes})$ \\
\hline & & $\begin{array}{l}\text { Social community } \\
\text { Involvement }\end{array}$ & Change measurement $(0=$ No, $1=$ Yes $)$ \\
\hline & Natural capital assets & Farmland & Change in Avg. amount in katha \\
\hline & \multirow[t]{4}{*}{$\begin{array}{l}\text { Physical capital } \\
\text { assets }\end{array}$} & Sanitation & $\begin{array}{l}1=\text { katcha, } 2=\text { pit, } 3=\text { Sanitary } \\
\text { (change in avg.) }\end{array}$ \\
\hline & & Household Property & Change in Avg. amount in katha \\
\hline & & House Type & $\begin{array}{l}1=\text { Detached }, 2=\text { semi-detached } \\
3=\text { Katcha, } 4=\text { Semi-Pucca, } 5=\text { Pucca } \\
6=\text { Terraced }\end{array}$ \\
\hline & & $\begin{array}{l}\text { Use of TV, Mobile, } \\
\text { Family refrigerator, } \\
\text { Electric cooker and } \\
\text { Electric fan }\end{array}$ & Change measurement $(0=\mathrm{No}, 1=$ Yes $)$ \\
\hline & \multirow[t]{3}{*}{$\begin{array}{l}\text { Financial capital } \\
\text { assets }\end{array}$} & $\begin{array}{l}\text { Income from Crops, } \\
\text { Fishing, Vegetation, } \\
\text { Poultry and Non } \\
\text { Agricultural sector } \\
\end{array}$ & Change avg. monthly amount in taka \\
\hline & & \begin{tabular}{|l|} 
Saving in Bank, Post \\
office, Personal saving, \\
and Life insurance
\end{tabular} & Change avg. monthly amount in taka \\
\hline & & $\begin{array}{l}\text { Investment In all } \\
\text { sectors }\end{array}$ & $\begin{array}{l}\text { Change avg. amount in taka in the } \\
\text { project period }\end{array}$ \\
\hline \multirow{3}{*}{$\begin{array}{l}\text { Vulnerability } \\
\text { context }\end{array}$} & & Hazard facing & $0=$ No, $1=$ Yes \\
\hline & & Types of hazard & $\begin{array}{l}1=\text { cyclone }, 2=\text { drought, } 3=\text { flood, } \\
4=\text { others }\end{array}$ \\
\hline & & $\begin{array}{l}\text { Support type during/ } \\
\text { after a disaster }\end{array}$ & $\begin{array}{l}1=\text { no support }, 2=\text { only training, } \\
3=\text { relief, } 4=\text { shelter }\end{array}$ \\
\hline \multirow{3}{*}{$\begin{array}{l}\text { Livelihood } \\
\text { Strategies }\end{array}$} & \multirow[t]{2}{*}{ Coping strategy } & Strategy identification & Through the change of assets \\
\hline & & Loaning \& investment & $\begin{array}{l}\text { Loaning amount, payment strategy, and } \\
\text { investment sector identification }\end{array}$ \\
\hline & Livelihood security & Saving strategy & $\begin{array}{l}\text { Relation with income and expenditure } \\
\text { (equation 1) }\end{array}$ \\
\hline \multirow[t]{3}{*}{$\begin{array}{l}\text { Livelihood } \\
\text { outlook }\end{array}$} & \multirow{3}{*}{$\begin{array}{l}\text { Economic status } \\
\text { improvement }\end{array}$} & Headcount Ratio & Equation 2 \\
\hline & & Poverty gap & Equation 3,4 and 5 \\
\hline & & Income inequality & Gini index \\
\hline
\end{tabular}




\begin{tabular}{|c|c|c|c|}
\hline Type of factors & Sub factors & Variables & Measurement \\
\hline & \multirow[t]{3}{*}{$\begin{array}{l}\text { Women } \\
\text { empowerment }\end{array}$} & $\begin{array}{l}\text { Income working } \\
\text { women. }\end{array}$ & $\begin{array}{l}\text { Measurement of the change of pre and } \\
\text { post-project. }\end{array}$ \\
\hline & & $\begin{array}{l}\text { A number of working } \\
\text { women. } \\
\end{array}$ & $\begin{array}{l}\text { measurement the change of pre and } \\
\text { post-project }\end{array}$ \\
\hline & & $\begin{array}{l}\text { Savings of working } \\
\text { women. }\end{array}$ & $\begin{array}{l}\text { measurement the change of pre and } \\
\text { post-project }\end{array}$ \\
\hline & Food security & $\begin{array}{l}\text { Produce involvement } \\
\text { in Rice, Fish, } \\
\text { Vegetable, Fruit, } \\
\text { Milk, Egg production }\end{array}$ & Change measurement $(0=\mathrm{No}, 1=$ Yes $)$ \\
\hline & Expenditure Sector & $\begin{array}{l}\text { Food, Cloth, } \\
\text { Education, Utility, } \\
\text { Medical and } \\
\text { Agriculture sector } \\
\end{array}$ & Change avg. monthly amount in taka \\
\hline & \multirow[t]{7}{*}{ Unions comparison } & HH property, & Change in avg. katha \\
\hline & & Farmland property, & Change in avg. katha \\
\hline & & Occupation change, & Change in frequency \\
\hline & & Pucca house, & Change in frequency \\
\hline & & Avg. income & Change avg. monthly amount in taka \\
\hline & & Avg. saving & Change avg. monthly amount in taka \\
\hline & & $\begin{array}{l}\text { Avg. Expenditure in } \\
\text { business }\end{array}$ & Change avg. monthly amount in taka \\
\hline
\end{tabular}

Source: Author, 2019

To identify the project's economic success in poverty reduction, well-known poverty count and gap identification measures were added in the outcome section. Income and savings change of working women is also considered the base of women empowerment, measuring the project's fruitfulness. The monthly expenditure sector (i.e., food, cloth, medical, etc.) was also considered, and also changes in housing and financial assets were taken into account to delineate the structural and most crucial financial progress among the union.

For identifying the saving structure as a livelihood strategy, a multiple linear regression was formed, taking saving after the project participants as the dependent variable and post-project income and expenditure as the independent variable. Personal avg. Income was taken with significant personal sectors (i.e., food, cloth, education, utility, and medical) expenditure. So, the following equation could be formed:

Savings $=$ Intercept $+\mathrm{B}_{1}{ }^{*}$ Income + Expenditure $\left\{\left(\mathrm{B}_{2}{ }^{*}\right.\right.$ Food $)+\left(\mathrm{B}_{3}{ }^{*}\right.$ Cloth $)+\left(\mathrm{B}_{4}{ }^{*}\right.$ Education $)-$ $\left(\mathrm{B}_{5}{ }^{*}\right.$ Utility $)-\left(\mathrm{B}_{6} *\right.$ Medical $\left.)\right\}$ (equation:1)

$\left(\mathrm{B}_{1}, \mathrm{~B}_{2}, \mathrm{~B}_{3}, \mathrm{~B}_{4}, \mathrm{~B}_{5}\right.$, and $\mathrm{B}_{6}$ are the corresponding multiplier). 
For assessing the economic condition and poverty measuring after the project, several methods had been followed. At first, the HeadCount Ratio was determined, identifying the poorer people ratio (Nokrek et al., 2018), lived below the poverty line (5000 BDT/month (ADB, 2020), by the following equation:

Headcount ratio $(\mathrm{H})=\mathrm{q} / \mathrm{N} \quad$ (equation: 2 )

(where, $\mathrm{q}=$ is the number of households $(\mathrm{HH})$ whose income less than the poverty line expenditure and $\mathrm{N}$ is the total $\mathrm{HH}$ ).

To identify the gap between poorer income and the poverty line for overcoming the simplicity of HeadCount Ratio, the gap and the intensity of poverty had also measured through Poverty Gap (PG), Poverty Gap Index (PGI), and Squared Poverty Gap index (SPGI) by the following equations:

$$
\begin{array}{ll}
P G=\frac{1}{N} \sum_{i=1}^{q}\left(z-y_{i}\right) & \text { (equation: } 3) \\
P G I=\frac{1}{N} \sum_{i=1}^{q} \frac{\left(z-y_{i}\right)}{z} & \text { (equation: 4) } \\
S P G I=\frac{1}{N} \sum_{i=1}^{q} \frac{\left(z-y_{i}\right) *\left(z-y_{i}\right)}{z} & \text { (equation: 5) }
\end{array}
$$

(where, $\mathrm{N}$ is the sample population, $q$ is the total population, living below the poverty line $z$ and $y_{i}$ personal income of person $i$. measured is also used for comparing the relative gap of the poverty and avg. Lack of income from the poverty line (Ravallion, 2013). Again, the households' cumulative share of income was used for measuring the post-project income inequality by Gini Index (Chappelow, 2020) to determine the proportion of wealthy people.

\section{ANALYSIS AND INTERPRETATIONS}

Due to being in the household, most of the participants (39 out of 60) were female. Most of the participants completed secondary school (36\%), and almost $13 \%$ were illiterate due to low financial condition. Among the surveyed data, $92 \%$ was a married couple, and most of the men (around 57\%) are involved in the business, where most women are housewives. Small types of a business bound their income to a lower level, as most of the participants have an income range of 5 to 10 thousand, where $13 \%$ has below 5 thousand incomes.

\subsection{Changes in capital assets}

In table: 2, the change of capital assets with significance is shown, where among the human assets, variable training benefit, and children engagement in education has a significant change relative to pre-project condition. Although only $8 \%$ of the recipients got training through ABAK, most of them got the practical knowledge of the training, and the parents also learn the importance of child education. People involved in the same project enable grouping themselves and increasing the community bonding (as both entertainment and community involvement 
have highly significant t-values 2.43 and 4.04 respectively). Although the farmland has a significant change $(t=2.05, p<0.01)$, but the mean change is less $(0.07)$, a possible cause of less enlarging the farmland can be the high land value that prohibits the landowners from enlarging their land and farming on it. Several participants upgrade their latrines either katcha to pit.

Table 2: Change of capital assets in the pre to post-project period

\begin{tabular}{|c|c|c|c|c|}
\hline Sectors & After-Project & Pre-Project & $\begin{array}{l}\text { Mean of pear } \\
\text { difference }\end{array}$ & \begin{tabular}{|l}
$\mathrm{t}$ value \\
(with sig.)
\end{tabular} \\
\hline \multicolumn{5}{|l|}{ I. Human capital assets } \\
\hline Children enrolment in education & 1.38 & 1.32 & 0.06 & $2.05 *$ \\
\hline Health Improvement & 0.83 & 0.8 & 0.03 & 1.00 \\
\hline Training benefit & 0.12 & 0.03 & 0.083 & $2.32 *$ \\
\hline \multicolumn{5}{|l|}{ II. Social capital assets } \\
\hline Entertainment group involvement & 0.26 & 0.15 & 0.12 & $2.43^{* *}$ \\
\hline Social community Involvement & 0.52 & 0.30 & 0.22 & $4.04 * * *$ \\
\hline \multicolumn{5}{|l|}{ III. Natural capital assets } \\
\hline Farmland & 2.23 & 2.16 & 0.07 & $2.05^{*}$ \\
\hline \multicolumn{5}{|l|}{ IV. Physical capital assets } \\
\hline Sanitation & 2.48 & 2.33 & 0.15 & $2.87^{* *}$ \\
\hline Household Property (Katha) & 5.00 & 4.70 & 0.30 & $1.97 *$ \\
\hline House Type & 4.17 & 4.13 & 0.03 & 0.26 \\
\hline Use of TV & 0.95 & 0.88 & 0.07 & $2.05 *$ \\
\hline Use of Mobile & 0.98 & 0.92 & 0.07 & $2.05 *$ \\
\hline Family refrigerator & 0.63 & 0.40 & 0.23 & $4.24 * * *$ \\
\hline Electric cooker & 0.05 & 0.02 & 0.03 & 1.00 \\
\hline Electric fan & 0.98 & 0.95 & 0.03 & 1.43 \\
\hline \multicolumn{5}{|l|}{ V. Financial capital assets } \\
\hline \multicolumn{5}{|l|}{ a) Income } \\
\hline Crops & 1529.41 & 2058.82 & -529.41 & -1.75 \\
\hline Fishing & 294.12 & 848.48 & -606.06 & $-1.79 *$ \\
\hline Vegetation & 347.37 & 847.37 & -500.00 & $-2.44^{*}$ \\
\hline Poultry & 2297.30 & 486.47 & 1810.811 & $2.16^{*}$ \\
\hline Non-Agricultural & 6280.48 & 5170.73 & 1162.50 & $4.27 * * *$ \\
\hline \multicolumn{5}{|l|}{ b) Savings } \\
\hline Bank & 17015.83 & 8559.17 & 8456.67 & 1.02 \\
\hline Post office & 200.00 & 111.67 & 80.33 & 1.90 \\
\hline Personal & 577.97 & 176.27 & 401.79 & $5.88 * * *$ \\
\hline Life insurance & 21.67 & 8.33 & 13.33 & 1.38 \\
\hline \multicolumn{5}{|l|}{ c) Investment } \\
\hline In all sectors & 201700.00 & 100600.00 & 101100.00 & 1.01 \\
\hline
\end{tabular}

$* * * \mathrm{p}<.001, * * \mathrm{p}<.01, * \mathrm{p}<.05$

Source: Field survey, 2019 
Alternatively, pit to sanitary, and the change is significant. Besides, the housing property is changing significantly $(t=0.26, p<0.05)$. rather than the housing type $(t=0.26, p>0.05)$. Although several cases found to change the housing type semi-pucca to pucca, the housing property increase with the increase of home yard farming. Among the electronic uses, TV and mobile have a little change (although significant), the cause can be the high availability and demand of those make the participant as its user even the pre-project period.

On the other hand, the refrigerator is costly and needs affordability, which increases significantly with the post-project period $(\mathrm{t}=4.24, \mathrm{p}<0.001)$. The electric heater is not so popular among the villagers, and the fan was so popular that it was used in the pre-project period by almost all. Table 2 shows that the critical change in the income sector has occurred in the post-project period. Among the selected sectors, only poultry and non-agricultural sector income were increased ( $\mathrm{t}$ values 2.016 and 4.27 respectively), but all other sectors were decreased. Because the project pulls the participant to the non-agricultural sector (only $5 \%$ are farmers), the women who are housewives in pre-project periods engage in poultry farming (almost eight new farms found). Participants have engaged in business, and some buy rickshaws/van for their livelihood rather than agro-based production. Again, the cause of the increment of personal savings $(t=$ $5.88, \mathrm{p}<0.001$ ) in the post-project period (table: 2 ) can be the rigid rule of banking (although it is increasing) and post office as well as the extended period for life insurance in money back. The investment also increased, but as only a few participants invested a considerable amount, the mean got higher (around 8500 taka) but not significant.

\subsection{Influence of vulnerability context}

Among the participants, $67 \%$ said they faced one or multiple types of natural hazards, and among those, most of the flood (around 67\%). Table: 3, Represents the types of support participants got, and it shows that almost half of the participants got no support from the government or any other organization.

Table 3: Hazard and support percentage during/after the project period

\begin{tabular}{|l|l|l|l|l|}
\hline Factors & $1^{\text {st }}$ category & $2^{\text {nd }}$ category & $3^{\text {rd }}$ category & $4^{\text {th }}$ category \\
\hline Hazard types & Cyclone (nil) & Drought (nil) & Flood $(67 \%)$ & Others $(33 \%)$ \\
\hline Support types & No support (47\%) & Only training (3\%) & Relief $(42 \%)$ & Shelter $(8 \%)$ \\
\hline
\end{tabular}

(Source: Field survey, 2019)

These types of natural calamities reduce their average productivity and indicate the high exposer to the sustainability risk. They got relief from the union's chairman several times, but due to less training participation, the training benefit gets lower. According to their opinion (as the issue is controversial, exact frequency is missing), people in the current remarkable political institution get the more benefit from helping the related sector, which makes one side powerful and influences the overall condition of living. 


\subsection{Assets influenced livelihood strategies}

Strategy can be identified from the capital assets change (table: 2), where income sifts are observed (as non-agricultural income increased) and personal level savings and investment increasing. Loan taking is found as the most common strategy while identifying the source of the investments mentioned above. Most participants (almost 69\%) use loans to recover from financial and natural crises (table: 4) from government projects and NGOs. Grameen Bank, BRAC, ASHA are the most common NGOs to provide loans to the participant, although they are most in taking a loan from ABAK (51\%), as there is the flexibility of repaying the loan. In their opinion, most of them like to deliver the payment of the loan every week $(55 \%)$. The reason is behind that lower-income people try to repay the money as a smaller portion weekly, wherein at the end of the month a little money remains in their hand after expenditures, only those taking a large amount of loan (above 20000) try to repay it in a half-yearly or yearly basis where maximum recipients borrowed 10000 takas (48\%) (table: 5) for self-development from ABAK. They said that their obstacles or needs were fulfilled through the loan they first got, so they did not try to purchase a loan for the 2 nd time. After taking the loan, the most common sector is the non-agricultural business (53\%), like grocery shops, buying rickshaw/vans, or small local businesses. Khulna is a region for high production of fishes; some people invested their loans from $\mathrm{ABAK}$ to buy or develop fisheries or 'Gher.' Home yard vegetation and poultry sector also cover a considerable investment portion it getting popular among the housewives. After all, all those NGOs, ABAK projects, and political institutions help them continue the loaning and investment policy and deposit as livelihood security.

Table 4: Factors associate with livelihood strategies

\begin{tabular}{|l|l|l|l|l|}
\hline Factors & 1st category & 2nd category & 3rd category & 4th category \\
\hline $\begin{array}{l}\text { Recovery } \\
\text { sectors }\end{array}$ & $\begin{array}{l}\text { Self-try } \\
(28 \%)\end{array}$ & $\begin{array}{l}\text { Help from others } \\
(3 \%)\end{array}$ & $\begin{array}{l}\text { ABAK loan } \\
(51 \%)\end{array}$ & $\begin{array}{l}\text { A loan from } \\
\text { NGOs }(18 \%)\end{array}$ \\
\hline $\begin{array}{l}\text { Total loan amount } \\
\text { (thousands) }\end{array}$ & $\begin{array}{l}5-10 \\
(48 \%)\end{array}$ & $\begin{array}{l}10-15 \\
(19 \%)\end{array}$ & $\begin{array}{l}15-20 \\
(25 \%)\end{array}$ & $\begin{array}{l}\text { Above } 20 \\
(8 \%)\end{array}$ \\
\hline Loan amortization & $\begin{array}{l}\text { Weakly } \\
(55 \%)\end{array}$ & $\begin{array}{l}\text { Monthly } \\
(13 \%)\end{array}$ & $\begin{array}{l}\text { Half-yearly } \\
(26 \%)\end{array}$ & $\begin{array}{l}\text { Yearly } \\
(6 \%)\end{array}$ \\
\hline Investment sector & $\begin{array}{l}\text { Fishery and } \\
\text { vegetation } \\
(28 \%)\end{array}$ & $\begin{array}{l}\text { Poultry } \\
(13 \%)\end{array}$ & $\begin{array}{l}\text { Non-agro- } \\
\text { business } \\
(53 \%)\end{array}$ & $\begin{array}{l}\text { Others } \\
(6 \%)\end{array}$ \\
\hline
\end{tabular}

(Source: Field survey, 2019)

Again, saving in personal and in the bank is increasing (table: 2), which indicates a strategy of ensuring the participants' financial sustainability in terms of ensuring livelihood security. From the (equation:1), the saving structure is:

Savings $=0.01 *$ Income + Expenditure $\{(0.27 *$ Food $)+(0.09 *$ Cloth $)+(0.02 *$ Education $)-$ $(0.77 *$ Utility $)-(0.40 *$ Medical $)\}+519.52$ 
Although the regression model has reasonable acceptability $\left(\mathrm{R}^{2} \sim 0.5\right)$, it represents the community has a saving structure to follow, where expenditure in the food sector plays a crucial role in saving ( $\mathrm{t}=4.12, \mathrm{p}<0.001)$. Furthermore, other independent variables like income, utility, and medical expenditure are significantly influenced $(\mathrm{p}<.05)$ the saving structure. It varies among the participants, where the cloth expenditure is almost the same to individuals and all house have not the educational expenses.

\subsection{Strategies influenced livelihood outlooks}

Table 2 shows some significant changes (community, housing, non-agricultural income, and savings) in capital assets, helping to build an expected outcome (sustainable) of living. The most prominent sector of the post ABAK assessment is poverty reduction. Although Head Count Ratio is a simple measure, only $13.33 \%$ of people among the participant live below the poverty line. It is also not good news, as, in the current economy, poverty line income is so less, and the result represents the drawback of the project to pull that small portion out of the poverty line. For more differentiating the income from the poverty line, the comparison can be focused (table: 5 ), where the both PG and SPGI value is maximum (31.25, 6 and 0.01 respectively) in the Senhati, so the poverty gap is more here than the two unions (Jogipole and Senhati). In Senhati, the poorer participant found (as rickshaw/van puller) and its located on the other side of the Bhairab river, making the locality more inaccessible towards business. On the other hand, Jogipole falls beside the town area Fulbarigate, and Arongghata is near Daulatpur thana, which favors the local people for accessibility towards income.

Table 5: Value of PG, PGI \& SPGI of the Unions

\begin{tabular}{|l|l|l|l|}
\hline Union & PG & PGI (\%) & SPGI \\
\hline Arongghata & 1.25 & 1 & 0.004 \\
\hline Jogipole & 18.75 & 4 & 0.04 \\
\hline Senhati & 31.25 & 6 & 0.01 \\
\hline
\end{tabular}

(Source: Author, 2019)

In figure 3, the Lorenz curve is a graphical representation of income inequality or wealth inequality from the straight line (formal equality); Lorenz curve line explains that $40 \%$ of the household having $60 \%$ wealth of the society ( $65 \%$ in previous), Although, it represents not so much higher inequality for the near future there is a chance to those affluent communities to pull up the resources from the more impoverished community. In ABAK, there is a lack of help giving policy according to the income of the individuals. 


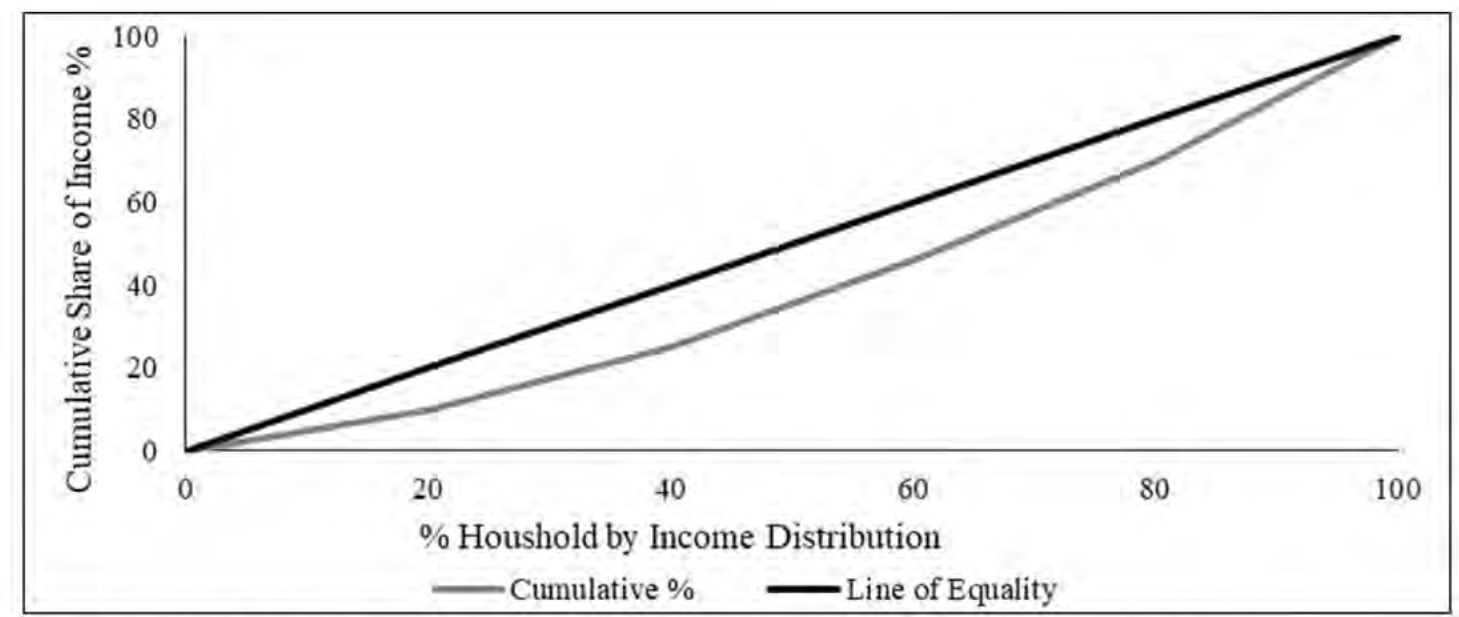

Fig. 3: Lorenz curve of cumulative income $\%$ vs. $\%$ household by income distribution (Source: Author, 2019)

After the poverty sector, the most critical sector is women empowerment through this project. The significant change in working women $(\mathrm{t}=5.33, \mathrm{p}<0.001)$ numbers indicate the strong influence of the project (table: 6). Besides housekeeping, the women started a vegetable garden, as it is easier and needs only a little investment to start. Again, the poultry farm is a profitable business; many female members are interested in forming a poultry farm. As a result, from the table: 6 , the significant ( $\mathrm{t}=6.83, \mathrm{p}<0.001$ ) increment of income (around $4000 /$ - avg.) from the women sector has been shown in the post period. The women's excess income than pre-project encourages them to save, and the change is also significant $(t=4.63, p<0.001)$. Among the participants, working women are interested in both personal and bank saving. Lack of farmland increment, the rice producer's frequency remains the same, and so no benefit is gained by this project in this sector (table: 6). Women participation in vegetation (along with more men participant that pre-project) increase the vegetable and fruit production in the area ( $\mathrm{t}=2.65$ and 3.37 respectively), so participant, as well as production, has changed in this sector.

Table 6: Women, producers, and expenditure sector change in pre to post-project

\begin{tabular}{|l|l|l|l|l|}
\hline Sectors & After-Project & Pre-Project & $\begin{array}{l}\text { Mean of pear } \\
\text { difference }\end{array}$ & $\begin{array}{l}\text { t value } \\
\text { (with sig. }\end{array}$ \\
\hline Women sector & 18 & 12 & $65.33^{* * *}$ & \\
\hline Number of working women & 18 & 2428.57 & 4342.11 & $6.83^{* * *}$ \\
\hline Income women workers & 6404.76 & 176.19 & 573.81 & $4.63^{* * *}$ \\
\hline Working women's saving & 750.00 & 0.33 & NA & NA \\
\hline Production sector (producer) & 0.33 & 0.18 & 0.01 & 1.05 \\
\hline Rice & 0.19 & 0.30 & 0.18 & $2.65^{* *}$ \\
\hline Fish & 0.48 &
\end{tabular}




\begin{tabular}{|l|l|l|l|l|}
\hline Sectors & After-Project & Pre-Project & $\begin{array}{l}\text { Mean of pear } \\
\text { difference }\end{array}$ & $\begin{array}{l}\text { t value } \\
\text { (with sig.) }\end{array}$ \\
\hline Fruit & 0.30 & 0.08 & 0.23 & $3.37^{* *}$ \\
\hline Milk & 0.20 & 0.01 & 0.20 & $3.12^{* *}$ \\
\hline Egg & 0.10 & 0.03 & 0.07 & $2.05^{*}$ \\
\hline Expenditures sector & 3637.5 & 2325.00 & 1312.50 & $5.06^{* * *}$ \\
\hline Food & 1276.47 & 900.00 & 376.47 & $6.10^{* * *}$ \\
\hline cloth & 2044.73 & 979.49 & 1065.78 & $4.05^{*}$ \\
\hline Education & 200 & 91.67 & 58.33 & 1.34 \\
\hline Utility & 1300 & 717.65 & 582.35 & $7.27^{* * *}$ \\
\hline Medical & 650 & 625 & 200 & 0.80 \\
\hline Agriculture &
\end{tabular}

(Source: Field survey, 2019)

Poultry farming and livestock farming (goat/cow) is started on a smaller scale than previous, increases the milk and egg production from those households. Food cost is found almost the same to the individuals, but as the consumption increases (along with income), the expenditure also increases (avg. 1300/- monthly) significantly in the post-project period $(t=5.06, p<0.001)$ in this sector (table: 6). Another expensive sector is education (increment avg. 1000/- month), the cause behind it the school going children have increased than the pre-project period. Other sectors (i.e., cloth, medical) also increased among the participants, but those expenditures are not regular. People usually buy cloth before the major religious festival, and medical cost occasionally happens time, but due to the change of income pattern the expenditure pattern also changed, and people tends to expend more in that sector for better social status and healthy life. A relative comparison among the unions in some common factors that influence the individual's socioeconomic status is plotted in Table 7. However, little changes occurred in the average household property of the members, average farmland property, several occupations changes people, pucca household type. From the table, the farmland property is more significant in the Senhati \& the response of household property is more in Arongghata. The significant change is focused on the union of Senhati, as it is located on another side of the Bhairab river; the most rural environment exists here, so the amount of farmland property is more considerable than the other two unions. It is seen that in the above all eight criteria, the condition of before and after ABAK has changed positively and efficiently. However, little change occurred in the average income, average savings, average expenditure on food, and average business investment.

Table 7: Relative comparison among the unions of the study area.

\begin{tabular}{|l|l|l|l|l|l|l|}
\hline \multirow{2}{*}{ Criteria } & \multicolumn{3}{|c|}{ Arongghata } & \multicolumn{2}{c|}{ Jogipole } & \multicolumn{2}{c|}{ Senhati } \\
\cline { 2 - 7 } & Former & After & Former & After & Former & After \\
\hline HS property & 4.15 & 4.46 & 3.31 & 3.39 & 3.02 & 3.32 \\
\hline Farmland property & 6.66 & 6.77 & 7.28 & 7.35 & 9.77 & 9.98 \\
\hline Occupation change & 0 & 3 & 0 & 6 & 0 & 8 \\
\hline
\end{tabular}




\begin{tabular}{|l|l|l|l|l|l|l|}
\hline \multirow{2}{*}{ Criteria } & \multicolumn{3}{|c|}{ Arongghata } & \multicolumn{2}{c|}{ Jogipole } & \multicolumn{2}{c|}{ Senhati } \\
\cline { 2 - 7 } & Former & After & Former & After & Former & After \\
\hline Pucca house & 11 & 14 & 25 & 27 & 15 & 19 \\
\hline Avg. income & 8465 & 9615 & 8215 & 9075 & 8095 & 8375 \\
\hline Avg. saving & 546 & 1000 & 396 & 788 & 175 & 772 \\
\hline Avg. expenditure & 2538 & 3192 & 2592 & 3111 & 2453 & 2640 \\
\hline Investment in business & 8000 & 9000 & 4000 & 4500 & 4000 & 5000 \\
\hline
\end{tabular}

(Source: Field survey, 2019)

The average income rate, average savings, average expenditure on food, the average investment in business all categories value is high in the Arongghata (table: 7). Again the village people Senhati tend to change their previous occupation (as most were farmers) to improve their status on a non-agricultural basis. Almost all the selection criteria are more or less improve to all the unions; in that perspective, $\mathrm{ABAK}$ is quite successful in bringing those socioeconomic transform.

\section{DISCUSSION OF RESULTS}

ABAK influences almost all capital assets sectors more or less significantly (table: 2). Although this project does not initiate new adult education, child enrollment in education indicates a more literate future generation to build up a more skillful community in the study area. ABAK also enables to target population in a healthy amount, but there is a lack of training participation, although whoever got training (a smaller portion of the participant) got more or less benefitted. People who participated in this program created a bond among themselves to conduct the project's everyday activities (i.e., the loan taking, loan repaying, participation in training, etc.). From this perspective, ABAK is successful in building up a positive change in social assets.

On the other hand, $\mathrm{ABAK}$ is not so useful to increase the farmland. The high land value and the change of occupation from pure firming are the leading cause behind it. The up-gradation of housing and sanitary structure (katcha to semi-pucca/pucca) prove the increment of social status in the post-project period. The most notable change of ABAK is occupational shift (agro-based to non-agro-based) influence the income policy and saving amount. As the farmland is not increasing, it is wise to shift the non-agricultural sector to ensure income and save security.

All the capital asset changes construct the livelihood strategies for better livelihood outcomes (Manlosa et al., 2019) until the vulnerability disrupts the livelihood. Another shortfall of the ABAK is that the lower support during/after the calamities (table: 3 ), although the area has a lower exposer to natural hazards (only seasonal flood). As there is little support from the concerned authority or ABAK (except loan), participants have adopted the strategy to take the loan and invest in the earning sector to repay that loan. As a result, most invest the loan in the business sector to earn profit and amortize the loan in a smaller portion weekly or monthly basis. Another most prominent strategy is housewives among the participants, who got involved in the earning sector that increased income and savings. In the Post ABAK periods, although the participants' expenditure has increased in several sectors (not only for consumption but also for 
the increment of commodities in pre to post-project periods), their saving behavior has been changed. Among all the complexities, participants in the project have successfully adopted the saving strategy (personal and bank) as livelihood security.

The project has a vast outcome in livelihood, in the occupational, women empowerment and productive sector, although it has less successfulness in poverty management. The poverty line income is not so much in current-day living, but some people are still living below the poverty line ( 8 out of 60 ). The poverty gap also high in the Senhati union (table: 5), although the income inequality is (fig: 3 ) is not so prominent among the participant, income sector in some fields (crops, fishing) in decreasing than previous, all those signify lower management in the financial sector of the project. Participants object to the low loan, and its amortization policy discourages the people from being involved in the project. On the other hand, the project is successful in the women sector. ABAK has significantly increased the number, income amount, and saving of women (table: 6). Due to these projects, several women got part-time jobs (i.e., record writer in school). After getting that job, they can solve their hardship and live a better life than before. Another outcome of the project is getting involved in the husband's business, and so the condition of business got better, and the economic status increased due to ABAK's help. Besides, involving in poultry farming \& dairy farming (an appreciable number of women members in Senhati became members of ABAK and took loans due to form poultry farms to income extra allowance beside their primary income) increases the number of the producer in this sector as well as their production. So, women who were dependent on the family's income now become economically independent and self-reliant. There can be no direct effect of ABAK in expenditure increment (table:6), as pre ABAK period commodities were relatively lower price. The post project's indirect effect is that it has increased the socioeconomic status and consumption, which increase the expenditure in some selected sectors. Besides, increment in most of the standard socioeconomic criteria (see table 7) (i.e., HH types, income, expenditure, property) in all unions are also indicating the success of the project in those fields.

\section{CONCLUSION}

Based on the Amar Bari Amar Khamar project's aim (solving the poverty problem and used the agricultural aspect in this regard), the study was conducted to assess the post-project impact on the participant's livelihood in terms of poverty reduction and women empowerment. The study ends with a significant positive change in the capital assets, non-agricultural sift to the income, and vital women empowerment with the significant saving tendency. By engaging the small parcel land into production, it counteracts the problem of employment and food security. A fair amount of recipients ABAK gets as it provides the self-sufficiency and self-development options and a considerable amount of options to reduce unemployment. The project's success is limited to poverty reduction. Deprivation of regular monitoring by field worker, no access to take loan greater the amount of 10,000 taka in one time, having disparity for choosing the member, these reasons are performed actively in the background of limitation. The project also habituated the members with the concept of saving, which generally is not seen in a rural area. One of the main setbacks we found in the study is that training was not given to the member who was one of the project's essential features. 
To minimize the limitations and shortcomings, integrated communication scope with members and staff of ABAK, choosing the least benefitted and most deprived villagers as target audience, reducing corruption in the project, nullifying the pressure of local lenders are eligible steps to inherit. For more efficiency in maintaining strategies, especially for providing training facilities, electronic communication system (mobile phone, email) allowance, strategical tool providing (chart, notebook) can be added on the project. People lose interest since loans are not well distributed; income-wise loaning policy can be developed to solve the problem. Biasness and nepotism, along with the communication between members and officers, needed to eradicate to accelerate the project's success. Future researchers should overcome the limitation of the study. More unions with many the dataset will give a more stable income, expenditure, and saving structure.

Moreover, the study uses headcount ratio, poverty gap, and income inequality for the identification of poor people in the study area and in order to measure the poverty severity and wealth imbalance, which determine the monetary change based on income but a more diverse estimate can produce more accurate measurement as poverty is something more of that. The production and consumption amount would be shown to identify the change in those sectors. Above all, the study will help find out the shortcoming and influencing sectors of rural development projects in Bangladesh and any other developing countries and help the researchers find the relation of capital assets influencing the livelihood strategies to make livelihood outcome in the context of vulnerability.

\section{ACKNOWLEDGMENT}

At the outset, all praises belong to Almighty Allah, the Most merciful, the most beneficent to all creatures and their dealings. We would like to express our gratitude to our honorable teachers Dr. Md. Mustafa Saroar, head and professor, Department of Urban and Regional Planning, KUET and Azmeri Ferdous, Lecturer, Department of Urban and Regional Planning, KUET, for his continuous guidance, supervision, directions, and suggestions at all stages, which was very helpful to conduct the research successfully. We would then like to thank the accommodating officials of the ABAK office, Dighalia Branch, for their heartfelt attempt to help get a better understanding of ABAK. Finally, we express our highest gratitude to the beautiful people of Arongghata, Jogipole, and Senhati.

\section{REFERENCES}

ADB. (2020). Poverty Data:Bangladesh. Retrieved from https://www.adb.org/countries/bangladesh/poverty\#: :text=In\%20Bangladesh\%2C\%20the\%20pop ulation\%20living, $2016 \% 20$ to\% $209.2 \% 25 \% 20 \mathrm{in} \% 202019$.

Ahmed, S., \& Sattar, Z. (2004). Trade Liberalization, Growth and Poverty Reduction: The Case of Bangladesh. Retrieved from http://documents1.worldbank.org/curated/en/ 598241468205488437/pdf/342040BD0rev.pdf
Banglapedia.
(2015a).
Rural
Development.
Retrieved
from http://en.banglapedia.org/index.php?title=Rural_Development 
Banglapedia. (2015b). Swanirvar Movement. Retrieved from http://en.banglapedia.org/index.php?title=Swanirvar_Movement

Begum, E. A. (2015). Rural Development in Bangladesh since Independence: A Study on Progress and Performance. Asian Journal of Agricultural an Rural Development, 452-464.

Chappelow, J. (2020). Investopedia. Retrieved from https://www.investopedia.com/terms/g/gini-index.asp

Gainee, A. F. (2014). A Case Study of Rural Development Programmes In India. International Journal of English Literature, Language and Humanities, 1.

GLOPP. (2008). DFID's Sustainable Livelihoods Approach and its Framework. Retrieved from http://www.glopp.ch/B7/en/multimedia/B7_1_pdf2.pdf

Gupta, A. K., Negi, M., Nandy, S., Alatalo, J. M., Singh, V., \& Pandey, R. (2019). Assessing the vulnerability of socio-environmental systems to climate change along an altitude gradient in the Indian Himalayas. Ecological Indicators, 106.

Harper, A., Harper, M., \& Poulton, C. (2020). The sustainable livelihoods framework. Retrieved from https://www.soas.ac.uk/cedep-demos/000_P528_RF_K3736-Demo/unit1/page_22.htm

Hossain, M. I., Begum, M. E., Papadopoulou, E., \& Semos, A. (2012). Rural Development in Bangladesh since Independence: A Study on Progress and Performance. Asian Journal of Agriculture and Rural Development, 2(3), 452-464.

Howlader, H. O. (2017). Contributory Micro Savings Nexus in Ektee Bari Ektee Khamar A Strategic Approach to the Poorest. World Vision Research Journal, 11(1), 85-102.

Manlosa, A. O., Hanspach, J., Schultner, J., Dorresteijn, I., \& Fischer, J. (2019). Livelihood strategies, capital assets, and food security in rural Southwest Ethiopia. Food Security, 11, 167-181.

Nokrek, P., Barmon, B. K., \& Rahman, S. (2018). Poverty, Income Inequality and Determinants of Income of the Ethnic Communities of Bangladesh. Asian Development Perspectives, 188-201.

Ravallion, M. (2013). Issues in Measuring and Modeling Poverty. Policy Research Working Papers. doi.org/10.1596/1813-9450-1615

Roodman, D. (2012). Grameen Bank Portfolio Continues Deteriorating. Retrieved from https://www.cgdev.org/blog/grameen-bank-portfolio-continues-deteriorating

Talukder, D., \& Chile, L. (2014). A Survey on Agricultural Trade Policies in Bangladesh: theoretical Insights and empirical Evidence. Journal of Economics \& Business Research, 20(1).

UNDP. (2017). Application of the Sustainable Livelihoods Framework in Development Projects. Retrieved from https://www.undp.org/content/dam/rblac/docs/ Research\%20and\%20Publications/Poverty\%20Reduction/UNDP_RBLAC_Livelihoods $\% 20$ Guidance\%20Note_EN-210July2017.pdf 